\title{
Modified Hiltner Dew Balance to Re-Estimate Dewfall Accumulation as a Reliable Water Source in the Negev Desert
}

\author{
Amber J. Hill ${ }^{1}$, Noa Kekuewa Lincoln ${ }^{2}{ }^{-}$, Shimon Rachmilevitch ${ }^{3}$ and Oren Shelef ${ }^{4, *(D)}$ \\ 1 The Albert Katz International School for Desert Studies, The Jacob Blaustein Institutes for Desert Research, \\ Ben-Gurion University of the Negev, Sede Boqer Campus, Midreshet Ben-Gurion 84990, Israel; \\ bamerbright@gmail.com \\ 2 Department of Tropical Plants and Soil Sciences, University of Hawai'i at Mānoa, 3190 Maile Way, \\ St. John 102, Honolulu, HI 96822, USA; nlincoln@hawaii.edu \\ 3 French Associates Institute for Agriculture and Biotechnology of Drylands, The Jacob Blaustein Institutes for \\ Desert Research, Ben-Gurion University of the Negev, Sede Boqer Campus, Midreshet Ben-Gurion 84990, \\ Israel; rshimon@exchange.bgu.ac.il \\ 4 Department of Natural Resources, Institute of Plant Sciences, Agricultural Research Organization, Volcani \\ Center, Rishon LeZion 7505101, Israel \\ * Correspondence: shelef@volcani.agri.gov.il
}

Received: 29 July 2020; Accepted: 15 October 2020; Published: 21 October 2020

\begin{abstract}
Dew formation is an essential component of the water balance in dry ecosystems, but measuring dew is challenging due, in part, to its dependency on the surface on which it forms. We detail the use of a modified Hiltner dew balance to illustrate how more accurate measurements of dewfall may be obtained. Using a modified Hiltner dew balance, we measured dewfall in the Negev Desert continuously for 3 years (2013-2015). Data analyses examined the relationship between dew formation, rain events and other environmental parameters in order to re-evaluate the importance of dew in the water budget. In line with previous research, our findings demonstrate that dewfall is a substantial and stable input of water in the Negev desert, providing inputs in the dry summer and the wet winter. Our results show that while dewfall was larger and more prevalent in proximity to rain events, a notable portion of dewfall took place on days distant from any rain event. The Hiltner dew balance modifications proved to be reliable and increased the efficacy of measuring the quantity and timing of dew formation. This study demonstrates the importance of integrating dewfall data into decision-making models for dryland ecosystems and agriculture, as well as into climate models.
\end{abstract}

Keywords: dew; Hiltner balance; water balance; desert; isotope

\section{Introduction}

Dew is a substantial component of the hydrology in dryland ecosystems. It is therefore essential to measure and understand dew formation in these systems in order to trace the ecosystem water balance [1,2] and study plants' physiology and their adaptations to water shortages [3-5]. Beyond the study of natural processes, understanding the food-water-energy nexus [6] is crucial for desert agriculture, particularly in light of the increasing population and demand for food production in these systems $[7,8]$.

Measuring dew is an ongoing challenge due to the dependency of dew formation on the accumulation surface, leading to inherent issues of accuracy in measuring both occurrence and quantity [9]. Dew formation only occurs when there is enough available moisture and efficient cooling, and it is typically driven by nocturnal radiation. Surface parameters for dew accumulation, such 
as surface texture and latent heat conductivity, greatly affect dew formation and therefore strongly influence dew measurement. There have been multiple attempts to indirectly measure dewfall or dew potential. Modeling dew potential based on microclimatic conditions provides a proxy for relative dew amounts [10]. Similarly, isotopic tracers have been used to estimate dewfall proportions [11-13]. However, the need to convert potential dewfall into actual dewfall or to calibrate isotopic mixing models still ultimately relies on accurately measuring atmospheric water condensation in an artificial surface accumulation [14]. Measuring the accumulation of condensed water on an artificial surface is a satisfactory, albeit imperfect, estimation of dew formation that has long been used and is still the best available proxy.

Many different devices have been designed to measure dew, such as lysimeters and dew gauges that make use of weight, optical methods or surface-wetness recorders [15-17]. However, the most commonly used instrument for dew measurement is the Hiltner dew balance (Lambrecht meteo GmbH, Göttingen, Germany). Data obtained from the Hiltner dew balance provide a quantitative measure of "potential dew", or the capacity of the air above the soil surface to provide condensate (liquid water), as a function of atmospheric conditions [18]. Observations by [19-24] Duvdevani (1947), Gilead and Rosenan (1954), Evenari and Shanan (1971), Zangvil (1996), Kidron (1999), and Kidron et al. (2002) established the Hiltner dew balance as a prominent instrument for measuring dew accumulation. Due to the importance of the accumulation surface, a standard material and method is essential for comparable results across studies that can be used to calibrate models. However, to date, measuring dew with the Hiltner balance is not performed with a standard surface. The main modification we suggest in this study is to replace the drum meter with a continuous digital data logger. This study aimed to evaluate the function of the modified Hiltner balance as a dew collector.

Beyond the absolute quantities of dew, the dew balance in a desert ecosystem has been estimated using isotopic methods. The stable isotopes of hydrogen and oxygen $\left({ }^{2} \mathrm{H}\right.$ and ${ }^{18} \mathrm{O}$, respectively) in rain, fog and dew water differ significantly in their concentrations and can therefore be used to trace the relative importance of these water sources in plants [25]. However, the isotopic signatures of these sources vary based on abiotic and biotic conditions, such as ground temperature, atmospheric conditions, and biological and topographical attributes [26].

Several studies have been conducted on the atmospheric dynamics of dew formation in dry ecosystems [9,27], the relative dew balance in those systems [25], and the impacts of atmospheric water on desert plants [28]. The desert is a unique ecological ecosystem in which low water availability makes dewfall a significant-and in some cases dominant-source of soil moisture [24,29-32].

The Negev Highlands is an arid ecosystem that exhibits substantial dew formation throughout most of the year $[25,27,31]$, providing an interesting location for studying dew. The Negev ecosystem, situated less than $120 \mathrm{~km}$ from the Mediterranean Sea, consistently exhibits critical combinations of air moisture and temperature differentials that drive dew formation. We pose the question: how predictable is the dewfall? More specifically, how do the timing and quantities of dewfall relate to rainfall events? The objectives of this study were (1) to measure dewfall inputs for the study site over several annual cycles, (2) to analyze the temporal relationship between rain events and dew formation, and (3) to re-evaluate the importance of dew in water-budget calculations.

The Negev desert typically experiences sporadic rainfall events during the winter, and local plants must tolerate the summer drought or else rely on other water sources, such as dewfall. We hypothesize that dew days are more likely to occur in proximity to rainfall events, concentrating dewfall in times when water shortage is not acute. This may explain why some plants appear to not incorporate dewfall into their water budget [25].To test this hypothesis, we deployed a Hiltner dew balance modified at Sede Boqer, University of Ben Gurion, for 3 years (2013-2015) to collect dew samples, coupled with meteorological data and isotopic measurements. 


\section{Materials and Methods}

\subsection{Study Area}

The study site is located at the Sede Boqer campus in the Negev highlands $\left(34^{\circ} 46^{\prime} \mathrm{E} 30^{\circ} 51^{\prime} \mathrm{N}\right.$; $460 \mathrm{~m}$ above sea level) in an arid desert environment. The average rainfall in the region is $90 \mathrm{~mm} / \mathrm{y}$ [33] and ranges from $25 \mathrm{~mm}$ in dry years to $150 \mathrm{~mm}$ in wet years [34], in approximately 25 rain days a year [35]. The vast majority of the rainfall occurs from November to March. For the duration of our study (2013-2015), an average of $114 \mathrm{~mm}$ of rain fell each year from 20 rain events averaging 10 days apart. Dewfall occurs year round in the Negev, on approximately 200-250 days a year, but most prominently in the months of September/October and January [22]. Kidron and Starinsky (2012) [35] measured an average of $0.2 \mathrm{~mm}$ of dewfall per event, and in our study, we found an average of approximately $0.1 \mathrm{~mm}$ per day.

\subsection{Hiltner Dew Balance}

The original Hiltner dew balance has an artificial surface fixed to the beam of a balance, where changes in weight are mechanically transmitted to a recording drum [15]. The beam balance is sensitive to air movement and has to be protected from wind. We examined the system in field conditions by recording and observing dew formation pre-dawn, to make sure that the wind barrier did not restrict dew formation. To improve its accuracy and provide continuous tracking of dew measurements, we connected the Hiltner dew balance to a data logger (Datalogger Compact Self-Contained Micrologger CR23X, Campbell Scientific, Logan, UT, USA; see Figure 1) to provide a continuous estimation of dew input. We connected the balance to a load cell (LC) [18]. The LC temperature was controlled (ambient air temperature $\pm 2{ }^{\circ} \mathrm{C}$ ) to eliminate any temperature effect by using a simple thermostat. The thermostat was controlled by the data logger, and the thresholds were adjusted seasonally to the minimum ambient temperature. To decrease wind and temperature effects, (1) the plate was suspended just above the soil surface with an air gap, thus effectively isolating it from the soil, and (2) the accumulation surface consisted of a thin PVC disc $(0.2 \mathrm{~mm})$, white in color and smooth in texture, with a minimal heat transfer capability (Figure 2). The area of the accumulation surface was calculated to provide an estimation of dew accumulation per unit area.

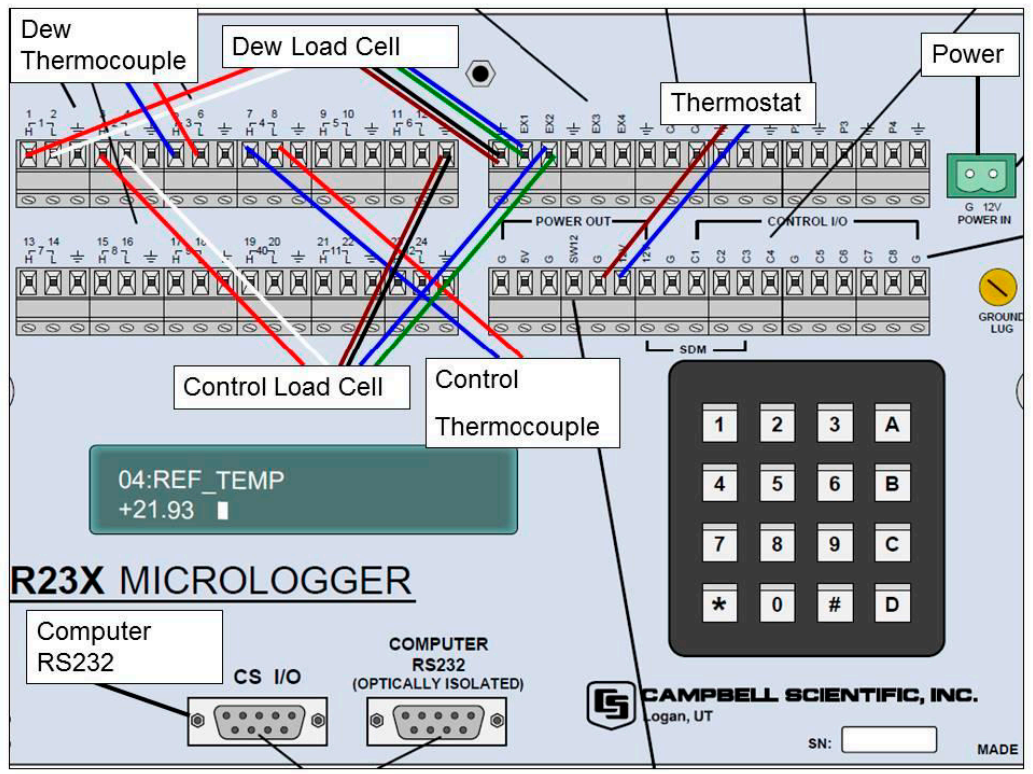

Figure 1. Schematic diagram of the R23X data logger. The data logger controls the thermostat to maintain a stable temperature within the range of the load cell (LC). Thermocouples and LC inputs are all traced by the R23X micrologger. 
A

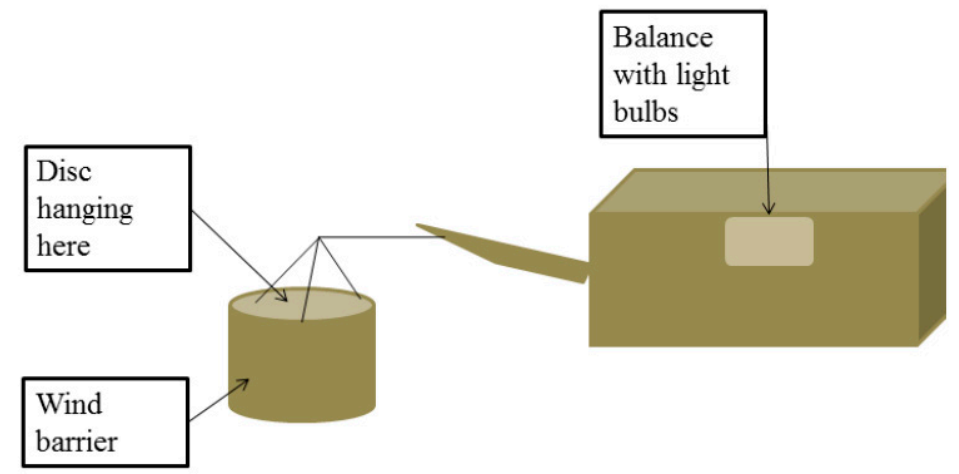

B

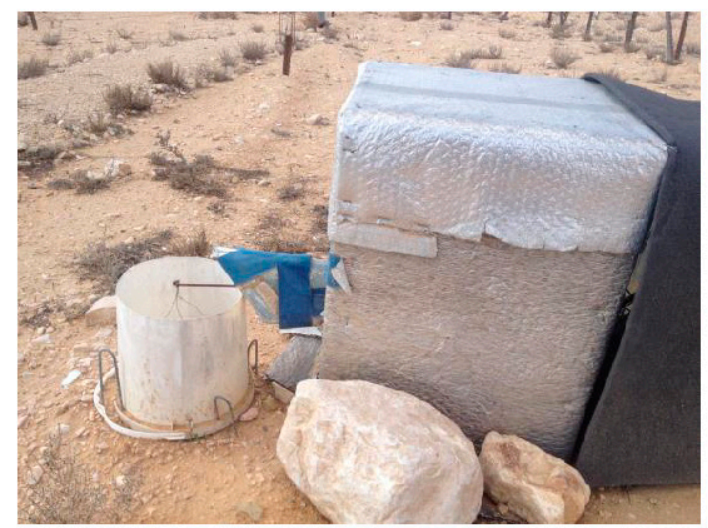

Figure 2. Modified Hiltner balance at the climate station of the Sede Boqer campus. (A) Schematic diagram of the whole Hiltner balance. (B) Side view of the Hiltner balance deployed in the field.

The data logger enabled the tracking of (1) the balance temperature, to ensure that any change in LC voltage was related to dew formation and not to a change in temperature; (2) the battery voltage, to ensure that any LC change was derived only from dew accumulation and was not a technical artifact; (3) the ambient temperature, by receiving electrical inputs from the thermocouple to measure temperature $40 \mathrm{~cm}$ from the device; and (4) the LC voltage. We used the following procedure to convert the LC voltage (millivolts) to dew accumulation and duration (in millimeters per square meter, equivalent to the precipitation of rain). A target temperature was defined as the average minimum temperature per month $+10^{\circ} \mathrm{C} \pm 1{ }^{\circ} \mathrm{C}$. A pair of headlight bulbs were connected to a thermostat, and temperature readings were set for turning the bulbs on and off so as to maintain the target temperature throughout the night (6 p.m. to 6 a.m.). This thermoregulation system was controlled by the data logger. The change in the balance weight each night was calculated as:

$$
D=W_{m}-W_{i}
$$

where $W_{i}$ is the initial balance weight, $W_{m}$ is the maximum balance weight during the night, and $D$ is the difference. In order to transform the voltage $(\mathrm{mV})$ to weight $(\mathrm{g})$, we used a calibration equation derived from millivolt readings of five known weights on the plate under field conditions, where:

$$
V=a W+b
$$

where $V$ is the LC voltage, $W$ is the weight of the balance, and $a$ and $b$ are the linear model constants.

In order to transform dew to precipitation equivalents $\left(\mathrm{mm} / \mathrm{m}^{2}\right)$, the water weight is scaled appropriately using the equation:

$$
D=\left(W / S A_{p}\right)
$$


where $D$ is the accumulated dew, $W$ is the calculated dew weight, and $S A_{p}$ is the surface area of the accumulation plate $\left(183.24 \mathrm{~cm}^{2}\right.$ in our case).

Noise was manually eliminated by ensuring that the balance temperature was stable during all measurements (evening to dawn) and that there were no rain events that day.

The following parameters were then identified and recorded:

- The time of the initial increase in balance weight (20\% of initial weight);

- The maximum weight change recorded as $D_{m}$ (dew at maximum);

- The time of the peak balance weight;

- The time of the decline in balance weight as a measure of the duration end (when sun radiation heats the surface plate, usually not later than 09:00 a.m.).

Readings that were under the detection threshold (an arbitrary threshold set at dew accumulation $<0.02 \mathrm{~mm}$ ) were discarded.

\subsection{Data Collection}

The dew, rain and weather data were collected as part of the long-term weather monitoring of the Negev area at the Sede Boqer meteorological station facility. The facility measures the following variables for hourly, daily, monthly and yearly averages: air temperature (at $1 \mathrm{~m}$ above sea level), relative humidity $(1 \mathrm{~m})$, total precipitation and total evaporation (Class A Pan) (https: //in.bgu.ac.il/en/bidr/Pages/meteorology-online.aspx). With the addition of the modified Hiltner dew balance, we were able to record the amount of dewfall throughout the night. Dew and weather data were collected from January 2013 to December 2015.

\subsection{Data Analysis}

Summary statistics were generated for all parameters of interest. Comparative time periods were analyzed by $t$-tests, with significance set at $p<0.05$. The isotope values were linearly regressed against meteorological data, including humidity and temperature. Dewfall data were cross-referenced with precipitation data from the meteorological station and analyzed for linear correlations.

\section{Results}

Annual dew formation was described from January 2013 to December 2015 in the Negev desert (Figure 3). The dewfall quantity was analyzed in discreet time periods to examine the temporal proximity of dewfall events to rain events. We developed a "time to" rain and a "time since" rain for each date and then analyzed the dewfall from that perspective (Figure 4). This approach demonstrates that there were more dew dates—and the largest dewfalls—near rain events. A highly significant, but very weak, linear relationship between the amount of dew and time since last rainfall $(p<0.0001$, $\left.r^{2}=0.03\right)$ indicates that across all times, slightly larger dew events occurred in proximity to rain events. However, a substantial contribution of total dewfall ( $51 \%)$ occurred more than a month after a rain event. 


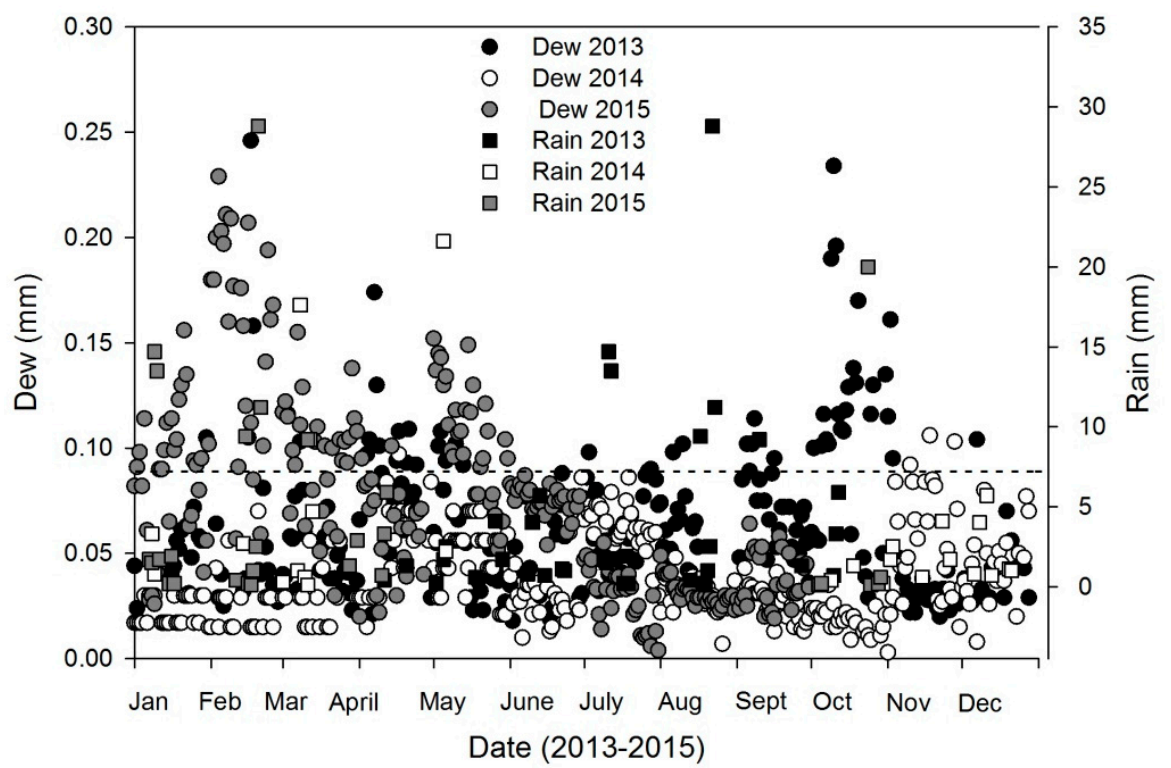

Figure 3. Amounts of dew and rain from January 2013 to December 2015 in the Negev desert, Israel. Black circles represent dew, and open squares represent rain. Dew formation of less than $0.02 \mathrm{~mm}$ was considered a technical artifact and was not included in the quantity analysis. Dashed line represents the average dew fall in Negev.

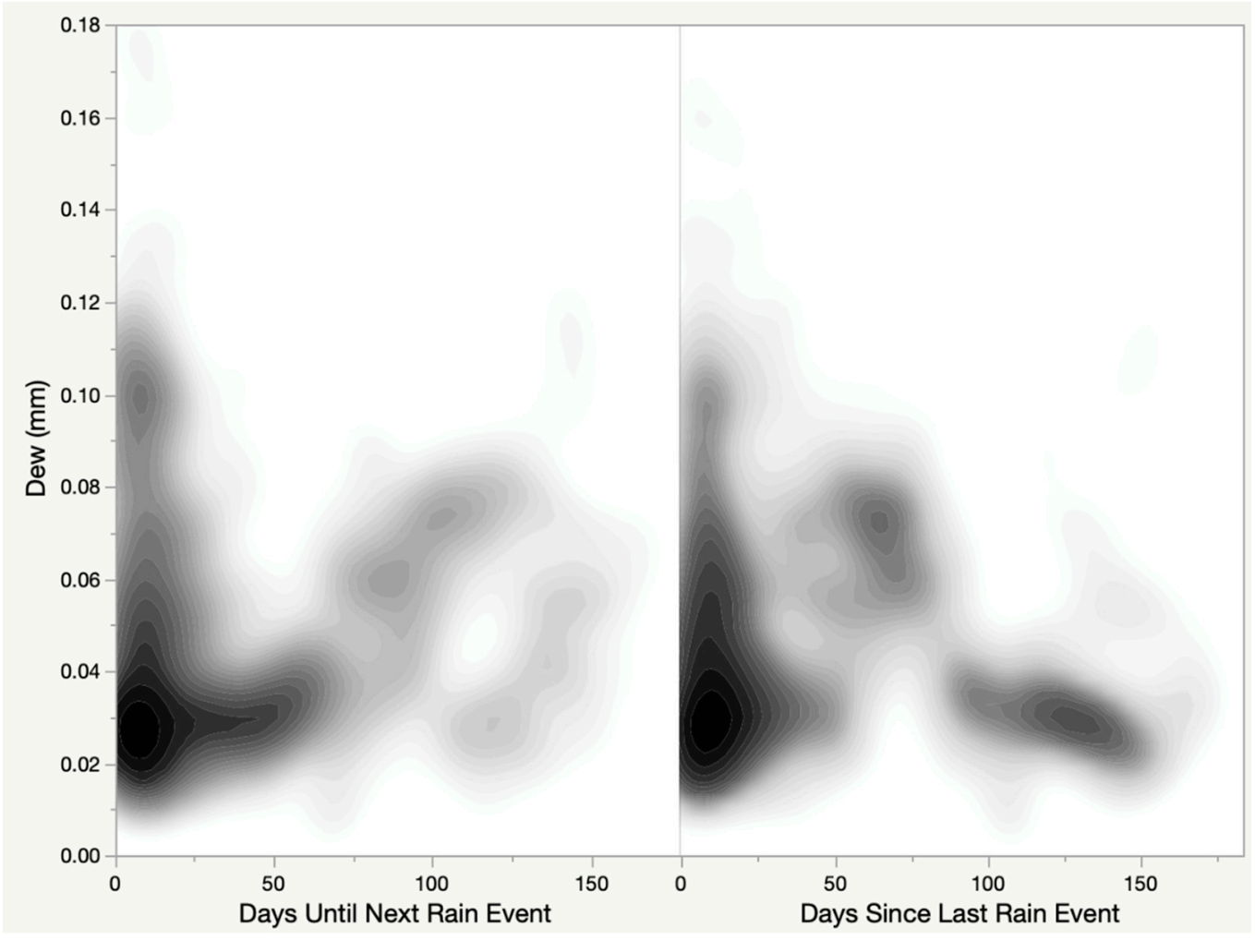

(A)

(B)

Figure 4. Heat map representing the density of dewfall amounts measured prior to (A) and following (B) rainfall events.

The dewfall and weather data were partitioned using different cutoff times (1-30 days) for being considered "before" or "after" a rainfall event (Table 1, Figure 5). Across all rain events, the average dew showed a slight increase leading up to a rain event, peaked immediately after the event (3-4 days) 
and diminished over the next 12 days. The increase in dew accumulation after 15 days from rain may be attributed to the proximity to the next cycle of the rain event. Temperature, humidity and vapor pressure had highly significant $(p<0.001)$, but very weak, linear relationships with dew formation, $\left(r^{2}\right.$ $=0.01,0.09$ and 0.05 , respectively). A multivariate regression using all the environmental parameters did not result in a higher $r^{2}$ value, suggesting that the environmental parameters co-vary in a way that has opposing effects on dew formation. For instance, as the air temperature increases, there is a greater temperature differential with the surface and therefore more dew formation. Additionally, as humidity increases, there is more moisture in the air and therefore more dew formation. In our study, temperature and humidity demonstrated a negative correlation $(r=0.41)$, so as one changed to increase dew formation, the other changed to cause a decrease.

Table 1. Average values of environmental factors as measured at the Sede Boqer meteorological station facility from January 2013 to December 2015.

\begin{tabular}{cc}
\hline Environmental Factors & Average \pm SD \\
\hline Humidity $(\%)$ & $69.88 \pm 0.12$ \\
Min. Temp $\left({ }^{\circ} \mathrm{C}\right)$ & $15.38 \pm 0.008$ \\
Max. Temp $\left({ }^{\circ} \mathrm{C}\right)$ & $29.91 \pm 1.83$ \\
Evaporation $(\mathrm{mm} /$ day $)$ & $8.66 \pm 0.41$ \\
Dew amount $(\mathrm{mm} /$ day $)$ & $0.08 \pm 0.001$ \\
Rainfall/year $(\mathrm{mm})$ & $126.51 \pm 4.53$ \\
Isotope value $\left(\delta^{18} \mathrm{O}\right)$ & $-1.98 \pm 0.12$ \\
Wind speed $(\mathrm{m} / \mathrm{s})$ & $7.15 \pm 1.11$ \\
\hline
\end{tabular}

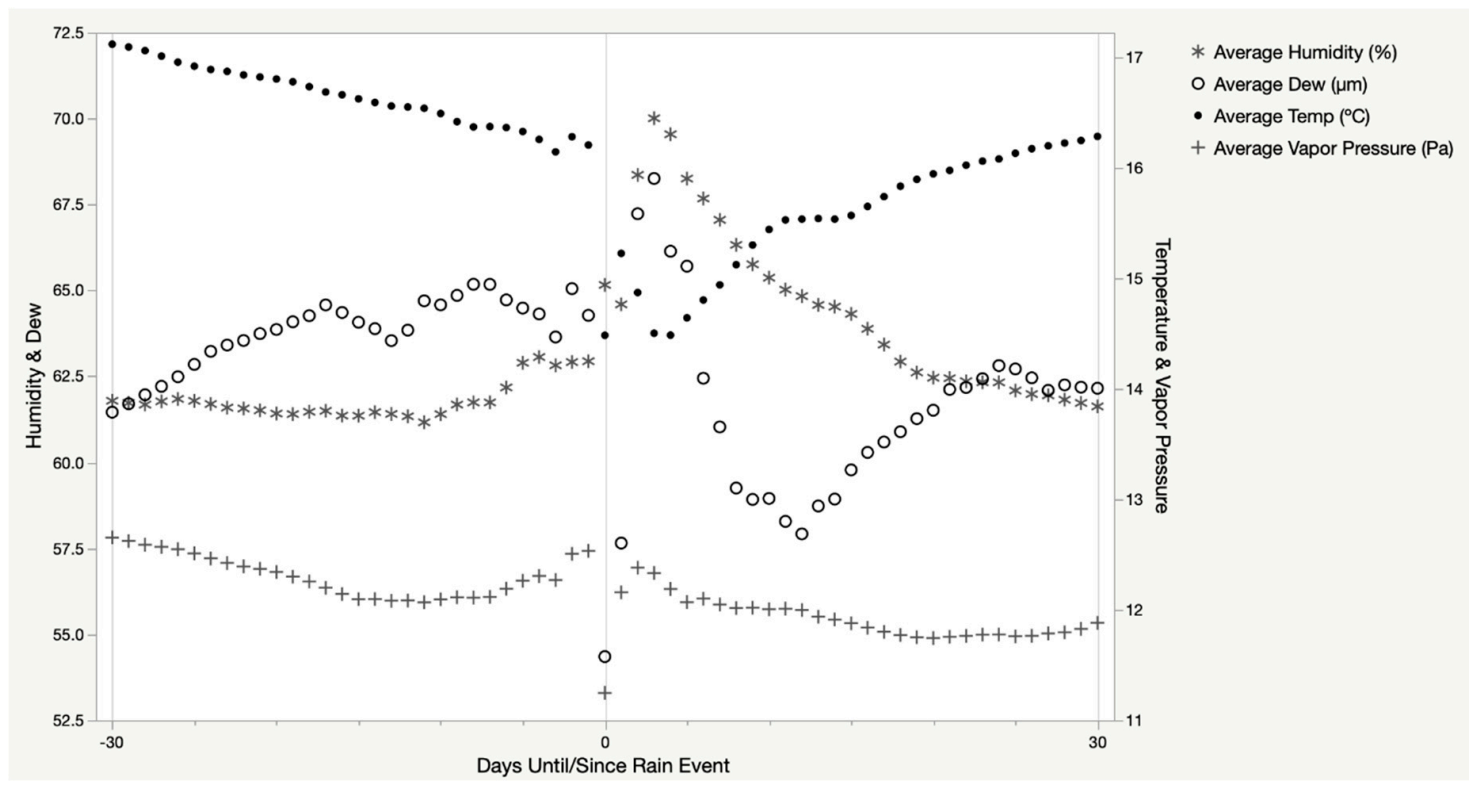

Figure 5. Mean humidity, dewfall, temperature and vapor pressure of different partitioning times leading up to, during and following a rain event.

A Local Meteoric Water Line (LMWL) representing the isotopic signatures of water $\left(\delta^{2} \mathrm{H}: \delta^{18} \mathrm{O}\right)$ was generated, showing a predictable linear relationship between the stable isotopes (Supplementary Materials, Figure S1).

\section{Discussion}

Water availability in the desert is essential for plant survival. To fully grasp the water balance in the desert, dew and its temporal patterns must be examined. We suggest that the modified Hiltner dew balance is a good method for directly measuring a valuable proxy of natural dewfall. Our study 
demonstrates the reliability of the modified Hiltner balance for measuring dewfall consecutively and in field conditions. We demonstrated how the dew amounts collected on the modified Hiltner balance are linked to the proximity to rain events, adding nuance to the role of dew in the hydrological cycle. We found that dewfall demonstrates strong temporal patterns surrounding rain events, with more dewfall immediately following rain events. This may be explained by atmospheric conditions that are in favor of dew accumulation. Interestingly, a substantial number of dew days occurred more than 30 days after a rain event. Across all three years, the total dewfall was $49.8 \mathrm{~mm}$, and $25.5 \mathrm{~mm}$ of that came more than 40 days after a rain event, equal to $51 \%$ of the total dewfall. This finding reiterates the importance of dew for desert plant survival [25]; this is especially relevant in a desert environment, where plants are dependent on limited water sources, due to the sparse, seasonal rain events. During the no-rain periods, the moisture in the air may be insufficient for rain but still precipitate as dew. Previous work has suggested that plants depend more heavily on dew in periods without rain [36-38]. Dewfall may be important for C-cycling in the soil as a result of the wetness provided by the dew to the ecosystem [39]. Interestingly, dew water was found to be enriched in nutrients compared to rainwater, with higher levels of $\mathrm{N}(\times 2.5), \mathrm{P}(\times 1.4)$ and $\mathrm{K}(\times 3.0)$ [35]. This suggests that the temporal patterns of dew may have other roles to play in addition to the water balance.

Previous studies have used isotopic values to predict ecosystem water balance $[13,40]$. Changes in the isotopic signature of the dew could be driven by (1) a difference in the isotopic signature of the atmospheric water vapor or (2) a change in the isotopic fractionation that occurs in the phase change from water vapor to condensation. Both of these could play a role, as increased humidity and dewfall are presumably driven by increased evaporation events that could result in changes to the isotopic signature of atmospheric water (Supplementary Materials, Figure S1). Just as meteoric water lines are established using specific local weather conditions, each ecological zone can be described by its own dew line. A local meteoric dew line can enable dew predictions and water efficiency for each area [41]. In this case, we can see that the dew line lies above the local water line (derived from local rain samples) and hovers close to the Eastern Mediterranean Meteoric Water Line (EMMWL) (see Supplementary Materials, Figure S1). This local dew line provides evidence that dew is being produced of its own accord, and the microhabitat conditions for Sede Boqer, independently of rain humidity. These meteoric lines can be used to integrate dew and rain isotopes into water-balance equations for irrigation purposes based on local weather conditions, without the need for isotopic measurements of the dew [42].

\section{Conclusions}

This study demonstrates the strength of using the modified Hiltner balance to study dewfall dynamics with field measurements. The modified system proved to provide reliable measurements and enhanced the ability to monitor dewfall throughout the night and evaluate the quantity and timing more precisely. In accordance with previous studies, our findings show that in the Negev desert, dewfall supplies a stable input of precipitation on an almost daily basis, and that this water resource can provide more than $30 \%$ of the annual average rain precipitation. Moreover, we asked how the dewfall is distributed throughout the year, and what its temporal proximity to rain events is. The importance of the dew is illustrated by the majority of dewfall (51\%) occurring more than 30 days after a rain event. Dew has been found to be important for plant survival in the desert, and our findings further explain the reliability of dewfall as a water source in an ecosystem that is characterized by unpredictable water availability. We found a correlation between dewfall accumulation and meteorological conditions, specifically, high humidity following a rain event. Our data show that the integration of dewfall data into decision-making models for dryland irrigation and humidity-related phytopathology is important, as is its integration into climate models.

Supplementary Materials: The following are available online at http://www.mdpi.com/2073-4441/12/10/2952/s1, Figure S1: Local Meteoric Water Lines (LMWLs) generated from rain or dew samples. 
Author Contributions: Conceptualization: A.J.H., O.S. and N.K.L.; methodology: A.J.H., O.S. and S.R.; analysis: A.J.H.; writing: A.J.H., O.S. and N.K.L.; supervision: O.S. and S.R. All authors have read and agreed to the published version of the manuscript.

Funding: This study was funded by the Israel Science Foundation (ISF project number 958/10).

Acknowledgments: We thank Ishai Hoffmann and Yuval Shani for their assistance in constructing the modifications to the Hiltner balance, and Pedro Berliner, Dody Avraham and Giora Kidron for early reviews of the manuscript and helpful commentary, and three anonymous reviewers for their thoughtful revisions.

Conflicts of Interest: The authors declare no conflict of interest.

\section{References}

1. Ben-Asher, J.; Alpert, P.; Ben-Zvi, A. Dew is a major factor affecting vegetation water use efficiency rather than a source of water in the eastern Mediterranean area. Water Resour. Res. 2010, 46, 1-8. [CrossRef]

2. Uclés, O.; Villagarcía, L.; Moro, M.J.; Canton, Y.; Domingo, F. Role of dewfall in the water balance of a semiarid coastal steppe ecosystem. Hydrol. Process. 2014, 28, 2271-2280. [CrossRef]

3. Pan, Y.X.; Wang, X.P.; Zhang, Y.F. Dew formation characteristics in a revegetation-stabilized desert ecosystem in Shapotou area, Northern China. J. Hydrol. 2010, 387, 265-272. [CrossRef]

4. Kidron, G.J.; Starinsky, A. Measurements and ecological implications of non-rainfall water in desert ecosystems-A review. Ecohydrology 2019. [CrossRef]

5. Kaseke, K.F.; Wang, L.; Seely, M.K. Nonrainfall water origins and formation mechanisms. Sci. Adv. 2017, 3, e1603131. [CrossRef]

6. Scanlon, B.R.; Ruddell, B.L.; Reed, P.M.; Hook, R.I.; Zheng, C.; Tidwell, V.C.; Siebert, S. The food-energy-water nexus: Transforming science for society. Water Resour. Res. 2017, 53, 3550-3556. [CrossRef]

7. Malek, E.; McCurdy, G.; Giles, B. Dew contribution to the annual water balances in semi-arid desert valleys. J. Arid Environ. 1999, 42, 71-80. [CrossRef]

8. Tomaszkiewicz, M.; Abou Najm, M.; Beysens, D.; Alameddine, I.; El-Fadel, M. Dew as a sustainable non-conventional water resource: A critical review. Environ. Rev. 2015, 23, 425-442. [CrossRef]

9. Agam, N.; Berliner, P.R. Dew formation and water vapor adsorption in semi-arid environments-A review. J. Arid Environ. 2006, 64, 572-590. [CrossRef]

10. Atashi, N.; Rahimi, D.; Al Kuisi, M.; Jiries, A.; Vuollekoski, H.; Kulmala, M.; Vesala, T.; Hussein, T. Modeling Long-Term Temporal Variation of Dew Formation in Jordan and Its Link to Climate Change. Water 2020, 12, 2186. [CrossRef]

11. Jacobs, A.F.; Heusinkveld, B.G.; Berkowicz, S.M. A simple model for potential dewfall in an arid region. Atmos. Res. 2002, 64, 285-295. [CrossRef]

12. Heusinkveld, B.G.; Berkowicz, S.M.; Jacobs, A.F.G.; Holtslag, A.A.M.; Hillen, W.C.A.M.; Heusinkveld, B.G.; Berkowicz, S.M.; Jacobs, A.F.G.; Holtslag, A.A.M.; Hillen, W.C.A.M. An Automated Microlysimeter to Study Dew Formation and Evaporation in Arid and Semiarid Regions. J. Hydrometeorol. 2006, 7, 825-832. [CrossRef]

13. Kaseke, K.F.; Tian, C.; Wang, L.; Seely, M.; Vogt, R.; Wassenaar, T.; Mushi, R. Fog Spatial Distributions over the Central Namib Desert-An Isotope Approach. Aerosol Air Qual. Res. 2018, 18, 49-61. [CrossRef]

14. Gat, J.R.; Airey, P.L. Stable water isotopes in the atmosphere/biosphere/lithosphere interface: Scaling-up from the local to continental scale, under humid and dry conditions. Glob. Planet. Chang. 2006, 51, 25-33. [CrossRef]

15. Noffsinger, T.L. Survey of techniques for measuring dew. In Humidity and Moisture; Reinhold: New York, NY, USA, 1965; Volume II, pp. 523-531.

16. Zhuang, Y.; Zhao, W. Dew formation and its variation in Haloxylon ammodendron plantations at the edge of a desert oasis, northwestern China. Agric. For. Meteorol. 2017, 247, 541-550. [CrossRef]

17. Karpenko, V. Amount of dew in the ussr, according to a dew recorder. Sov. Hydrol. 1972, 3, 260-263.

18. Ninari, N.; Berliner, P.R. The role of dew in the water and heat balance of bare loess soil in the Negev Desert: Quantifying the actual dew deposition on the soil surface. Atmos. Res. 2002, 64, 323-334. [CrossRef]

19. Duvdevani, S. An optical method of dew estimation. Q. J. R. Meteorol. Soc. 1947, 73, 282-296. [CrossRef]

20. Gilead, M.; Rosenan, N. Ten Years of Dew Observation in Israel. Isr. Explor. J. 1954, 4, 120-123.

21. Evenari, M.; Shanan, L.; Tadmor, N. The Negev: The Challenge of a Desert; Oxford University Press: Oxford, UK, 1971. 
22. Zangvil, A. Six years of dew observations in the Negev Desert, Israel. J. Arid Environ. 1996, 32, 361-371. [CrossRef]

23. Kidron, G.J. Altitude dependent dew and fog in the Negev Desert, Israel. Agric. For. Meteorol. 1999, 96, 1-8. [CrossRef]

24. Kidron, G.J.; Herrnstadt, I.; Barzilay, E. The role of dew as a moisture source for sand microbiotic crusts in the Negev Desert, Israel. J. Arid Environ. 2002, 52, 517-533. [CrossRef]

25. Hill, A.J.; Dawson, T.E.; Shelef, O.; Rachmilevitch, S. The role of dew in Negev Desert plants. Oecologia 2015, 178, 317-327. [CrossRef]

26. Dody, A.; Ziv, B. Factors affecting isotopic composition of the rainwater in the Negev Desert, Israel. J. Geophys. Res. Atmos. 2013, 118, 8274-8284. [CrossRef]

27. Zangvil, A.; Druian, P. Measurements of dew at a desert site in southern Israel. Geogr. Res. Forum 1980, 2, 26-34.

28. Vogel, S.; Müller-Doblies, U. Desert geophytes under dew and fog: The "curly-whirlies" of Namaqualand (South Africa). Flora Morphol. Distrib. Funct. Ecol. Plants 2011, 206, 3-31. [CrossRef]

29. Monteith, J.L. The reflection of short-wave radiation by vegetation. Q. J. R. Meteorol. Soc. 1959, 85, 386-392. [CrossRef]

30. Baier, W. Studies on dew formation under semi-arid conditions. Agric. Meteorol. 1966, 3, 103-112. [CrossRef]

31. Kidron, G.J. Angle and aspect dependent dew and fog precipitation in the Negev desert. J. Hydrol. 2005, 301, 66-74. [CrossRef]

32. Guo, X.; Zha, T.; Jia, X.; Wu, B.; Feng, W.; Xie, J.; Gong, J.; Zhang, Y.; Peltola, H. Dynamics of Dew in a Cold Desert-Shrub Ecosystem and Its Abiotic Controls. Atmosphere 2016, 7, 32. [CrossRef]

33. Yair, A. Complex geo-ecological responses to climatic changes in a dryland area: Northern Negev desert; Israel. AGUFM 2009, 2009, H24B-05.

34. Shanan, L.; Evenari, M.; Tadmor, N.H. Rainfall patterns in the central Negev desert. Isr. Explor. J. 1967, 17, 163-184.

35. Kidron, G.J.; Starinsky, A. Chemical composition of dew and rain in an extreme desert (Negev): Cobbles serve as sink for nutrients. J. Hydrol. 2012, 420-421, 284-291. [CrossRef]

36. Goldsmith, G.R.; Matzke, N.J.; Dawson, T.E. The incidence and implications of clouds for cloud forest plant water relations. Ecol. Lett. 2013, 16, 307-314. [CrossRef]

37. Goldsmith, G.R.; Lehmann, M.M.; Cernusak, L.A.; Arend, M.; Siegwolf, R.T.W. Inferring foliar water uptake using stable isotopes of water. Oecologia 2017, 184, 763-766. [CrossRef]

38. Dawson, T.E.; Goldsmith, G.R. The value of wet leaves. New Phytol. 2018, 219, 1156-1169. [CrossRef]

39. Berry, Z.C.; Emery, N.C.; Gotsch, S.G.; Goldsmith, G.R. Foliar water uptake: Processes, pathways, and integration into plant water budgets. Plant Cell Environ. 2019, 42, 410-423. [CrossRef]

40. Adar, E.M.; Dody, A.; Geyh, M.A.; Yair, A.; Yakirevich, A.; Issar, A.S. Distribution of stable isotopes in arid storms. Hydrogeol. J. 1998, 6, 50-65. [CrossRef]

41. Giustini, F.; Brilli, M.; Patera, A. Mapping oxygen stable isotopes of precipitation in Italy. J. Hydrol. Reg. Stud. 2016, 8, 162-181. [CrossRef]

42. Atkin, O.K.; Bloomfield, K.J.; Reich, P.B.; Tjoelker, M.G.; Asner, G.P.; Bonal, D.; Bönisch, G.; Bradford, M.G.; Cernusak, L.A.; Cosio, E.G.; et al. Global variability in leaf respiration in relation to climate, plant functional types and leaf traits. New Phytol. 2015, 206, 614-636. [CrossRef]

Publisher's Note: MDPI stays neutral with regard to jurisdictional claims in published maps and institutional affiliations.

(C) 2020 by the authors. Licensee MDPI, Basel, Switzerland. This article is an open access article distributed under the terms and conditions of the Creative Commons Attribution (CC BY) license (http://creativecommons.org/licenses/by/4.0/). 